УДК 616.98:579.842.23(470)

Н.В.Попов ${ }^{1}$ В.Е.Безсмертный르, А.Н.Матросов ${ }^{1}$, Т.В.Князева ${ }^{1}$, А.А.Кузнецов ${ }^{1}$, Ю.М.Федоров ${ }^{2}$, В.П.Попов ${ }^{2}$, Д.Б.Вержуцкий ${ }^{3}$, В.М.Корзун ${ }^{3}$, Е.В.Чипанин ${ }^{3}$, В.М.Дубянский ${ }^{4}$, О.В.Малецкая ${ }^{4}$, М.П.Григорьев ${ }^{4}$, С.В.Балахонов ${ }^{3}$, А.Н.Куличенко ${ }^{4}$, В.В.Кутырев ${ }^{1}$

ЭПИЗООТИЧЕСКАЯ АКТИВНОСТЬ ПРИРОДНЫХ ОЧАГОВ ЧУМЫ РОССИЙСКОЙ ФЕДЕРАЦИИ В 2014 г. И ПРОГНОЗ НА 2015 г.

${ }^{1}$ ФКУЗ «Российский научно-исследовательский противочумный институт «Микроб», Саратов, Российская Федерачия; ${ }^{2}$ ФКУ «Противочумный центр Роспотребнадзора», Москва, Российская Федерачия; ${ }^{3}$ ФКУЗ «Иркутский научно-исследовательский противочумный институт Сибири и Дальнего Востока», Иркутск, Российская Федерация; ${ }^{4}$ ФКУЗ «Ставропольский научно-исследовательский противочумный институт», Ставрополь, Российская Федерация

Целью исследований являлась оценка состояния паразитарных систем и активности природных очагов чумы Российской Федерации в 2014 г. и разработка эпизоотологического прогноза на 2015 г. В 2014 г. эпизоотии чумы выявлены на территории Горно-Алтайского высокогорного, Тувинского горного, Прикаспийского песчаного природных очагов чумы на общей площади 3890,2 кв. км. Выделено 128 штаммов чумного микроба, в том числе от грызунов и зайцеобразных - 24, от кровососущих членистоногих - 103. Один штамм чумного микроба получен от больного на территории Горно-Алтайского высокогорного природного очага чумы. Обоснован эпизоотологический прогноз на сохранение в 2015 г. напряженной эпидемиологической обстановки в Прикаспийском песчаном, Горно-Алтайском высокогорном и Тувинском горном природных очагах чумы. Подчеркнута необходимость использования эпизоотологических прогнозов в качестве основы для планирования и проведения эпидемиологического мониторинга и профилактических мероприятий в активных природных очагах чумы. В связи с различной эпидемиологической значимостью штаммов Y. pestis ssp. pestis, Y. pestis ssp. caucasica и Y. pestis ssp. altaica данные об их пространственном распределении необходимо использовать при дифференциации очаговых территорий по степени потенциальной эпидемической опасности.

Ключевые слова: природные очаги чумы, эпизоотическая активность, эпизоотологический прогноз, штаммы чумного микроба, носители и переносчики чумы, профилактические мероприятия, эпидемическая опасность.

N.V.Popov ${ }^{1}$, V.E.Bezsmertny ${ }^{2}$, A.N.Matrosov ${ }^{1}$, T.V.Knyazeva ${ }^{1}$, A.A.Kuznetsov ${ }^{1}$, Yu.M.Fedorov ${ }^{2}$, V.P.Popov ${ }^{2}$, D.B.Verzhutsky ${ }^{3}$, V.M.Korzun ${ }^{3}$, E.V.Chipanin ${ }^{3}$, V.M.Dubyansky ${ }^{4}$, O.V.Maletskaya ${ }^{4}$, M.P.Grigor' ${ }^{4}{ }^{4}$, S.V.Balakhonov ${ }^{3}$, A.N.Kulichenko ${ }^{4}$, V.V.Kutyrev ${ }^{1}$

\title{
Epizootic Activity of Natural Plague Foci in the Territory of the Russian Federation in 2014 and Prognosis for 2015
}

${ }^{1}$ Russian Research Anti-Plague Institute "Microbe", Saratov, Russian Federation; ${ }^{2}$ Rospotrebnadzor Plague Control Center, Moscow, Russian Federation; ${ }^{3}$ Irkutsk Research Anti-Plague Institute of Siberia and Far East, Irkutsk, Russian Federation; ${ }^{4}$ Stavropol Research Anti-Plague Institute, Stavropol, Russian Federation

Objective of the studies was to evaluate the state of parasitic systems and activity of the natural plague foci in the Russian Federation in 2014 and to develop epizootiological forecasting for 2015. In 2014 plague epizooties were detected in the territory of Gorno-Altaisk high-mountain, Tuva mountain, and Caspian Sea Region sandy plague foci, their total area amounting to $3890.2 \mathrm{~km}^{2}$. Isolated were 128 plague agent strains: from rodents and lagomorphs - 24, 103 - from bloodsucking arthropods. One strain was obtained from a patient in the territory of Gorno-Altaisk high-mountain natural plague focus. Substantiated has been epizootiological prognosis claiming persistent challenging epidemiological situation in the foci. Outlined is the necessity to use epizootiological forecasting as the basis for scheduling and carrying out epidemiological monitoring and preventive measures in active natural plague foci. Due to the varying epidemiological significance of Y. pestis ssp. pestis, Y. pestis ssp. caucasica, and Y. pestis ssp. altaica strains the data on their spatial distribution should be deployed for differentiation of focal areas according to the degree of the potential epidemic hazard.

Key words: natural plague foci, epizootic activity, epizootiological prognosis, plague agent strains, carriers and vectors of plague, preventive measures, epidemic hazard.

Вследствие аномального характера погодных условий 2013-2014 гг. паразитарные системы природных очагов чумы Кавказа, Предкавказья, Северного Прикаспия, Забайкалья продолжают оставаться в состоянии депрессии. Эпизоотии чумы выявлены в энзоотичных регионах Алтая (Республика Алтай, Республика Тыва) и на террито- рии Прикаспийской низменности в Северо-Западном Прикаспии (Астраханская область, Республика Калмыкия, Республика Дагестан). Наиболее сложная эпидемиологическая обстановка сложилась на территории Горно-Алтайского высокогорного природного очага, где впервые (начиная с 1961 г.) зарегистрирован случай заболевания человека [1]. 
Культуры чумного микроба (128 штаммов) выделены в Горно-Алтайском высокогорном (31), Тувинском горном (44) и Прикаспийском песчаном (53) природных очагах. Общая площадь выявленных эпизоотических участков составила 3890,2 кв.км. От носителей и переносчиков возбудителя чумы выделено 127 штаммов. Один штамм возбудителя выделен от человека. Из 127 штаммов 24 (18,9\%) изолированы от 7 видов грызунов и 1 вида зайцеобразных, $97(76,4 \%)$ выделены от блох и 6 (4,7\%) - от других переносчиков. Из 24 штаммов 9 (37,6 \%) получены от полуденной, 4 (16,6 \%) - от гребенщиковой песчанок, 4 (16,6\%) - от длиннохвостого суслика, $2(8,3 \%)$ - от домовой мыши, 2 (8,3\%) - от монгольской пищухи, 1 (4,2\%) - от алтайского сурка, 1 $(4,2 \%)$ - от малого тушканчика, 1 (4,2 \%) - от общественной полевки. Среди 16 зараженных видов блох штаммы (97) распределились следующим образом: Citellophilus tesquorum - 27 (27,8\%), Nosopsyllus laeviceps - 17 (17,5\%), Rhadinopsylla dahurica - 10 (10,3\%), Nosopsyllus mokrzeckyi - 8 (8,3\%), Paradoxopsyllus scorodumovi - 5 (5,2\%), Xenopsylla conformis -5 (5,2 \%), Paramonopsyllus scalonae - 4 (4,1\%), Neopsylla mana - $3(3,1 \%)$, Frontopsylla hetera -3 (3,1\%), Ctenophyllus hirticrus - 3 (3,1\%), Nosopsyllus consimilis - $3(3,1 \%)$, Paradoxopsyllus kalabukhovi 2 (2,1\%), Amphipsylla primaris primaris - 1 (1,0\%), Amphalius runatus - 1 (1,0\%), Frontopsylla elatoides 1 (1,0 \%), Oropsylla alaskensis - 1 (1,0\%), от блох без определения видовой принадлежности - $3(3,1 \%)$. Из 6 культур, выделенных от прочих переносчиков, 1 - от гамазовых клещей, 1 - от вшей грызунов (без определения вида) и 4 - от нимф и личинок иксодового клеща Dermacentor nuttalli.

Последний случай заражения чумой в России имел место в 1979 г. (п. Артезиан, Республика Калмыкия) на фоне резкой активизации Прикаспийского песчаного природного очага чумы после 25-летнего межэпизоотического периода (с 1954 г.). В 2014 г. вследствие оперативного и адекватного реагирования (специфическая и неспецифическая профилактика) на рост эпидемической опасности Прикаспийского песчаного очага было обеспечено эпидемиологическое благополучие по чуме. При этом эпизоотологический прогноз на его активизацию в весенний и осенний сезоны 2014 г. [3] послужил основой для своевременного планирования всего комплекса профилактических (противоэпидемических) мероприятий.

В 2014 г. значительно возросла потенциальная эпидемическая опасность территории ГорноАлтайского высокогорного природного очага, где зарегистрировано вовлечение в эпизоотический процесс промыслового вида - серого сурка и подтверждена высокая вероятность широкого распространения основного подвида чумного микроба - Yersinia pestis ssp. pestis [1]. Вплоть до 2012 г. здесь регистрировали штаммы только неосновного подвида чумного микроба Y. pestis ssp. altaica, которые обладают избирательной вирулентностью для лабораторных жи- вотных и носителей возбудителя, и не служили причиной заражения человека. В связи с регистрацией в 2012-2014 гг. в данном очаге высоковирулентных штаммов необходимо пересмотреть дифференциацию его территории по степени потенциальной эпидемической опасности с учетом ареалов основного и неосновного подвидов чумного микроба и внести коррективы в тактику эпизоотологического обследования участков, где зарегистрирована циркуляция высоковирулентных штаммов Y. pestis ssp. pestis.

Сохранение напряженной эпидемиологической обстановки также отмечено на территории Борошайского участка очаговости Тувинского горного природного очага, где в 2012 г. выделены культуры чумы от трупа монгольского сурка и его эктопаразитов (ур. Боро-Шай). Коренное население республик Алтай и Тыва, несмотря на активную работу природоохранных служб, отлавливает сурков (серого и монгольского) в границах стойких эпизоотических участков, что создает постоянную угрозу возникновения здесь эпидемических осложнений.

В энзоотичных по чуме регионах Кавказа, как и на Алтае, зарегистрирована циркуляция штаммов как основного - Y. pestis ssp. pestis (Центрально-Кавказский высокогорный), так и неосновного - Y. pestis ssp. caucasica (Восточно-Кавказский высокогорный) подвидов чумного микроба. В Центрально-Кавказском высокогорном природном очаге в районах Приэльбрусья значительно возросла интенсивность контактов постоянного и временного населения с природно-очаговыми комплексами (рост рекреационной нагрузки, миграционной активности временного населения). На территории Терско-Сунженского низкогорного природного очага чумы подтверждена циркуляция штаммов основного (1970-1971 гг.) и неосновного (1978 г.) подвидов чумного микроба. Случаев заражения человека чумой с участием штаммов $Y$. pestis ssp. caucasica на территории Российской Федерации не отмечено. Однако в Закавказском высокогорном очаге полевочьего типа (Армения), где также циркулируют штаммы Y. pestis ssp. caucasica, случаи бубонной чумы имели место в 1958, 1969 и 1975 гг. [2]. Так, в Гюмринском (Ленинаканском) мезооочаге в 1958 г. этот возбудитель был выделен от человека (штамм № 835). Учитывая возможность заражения человека возбудителем кавказского подвида, необходимо также повысить эффективность эпидемиологического надзора в границах его ареала (Восточно-Кавказский высокогорный, ТерскоСунженский низкогорный природные очаги). Кроме того, данные о пространственном распределении различных по эпидемиологической значимости штаммов $Y$. pestis ssp. pestis, Y. pestis ssp. caucasica $u$ $Y$. pestis ssp. altaica могут использоваться при дифференциации очаговых территорий по степени потенциальной эпидемической опасности.

В связи с сохранением напряженной эпидемиологической обстановки в Горно-Алтайском высокогорном, Тувинском горном и Прикаспийском песча- 
ном природных очагах чумы необходимо оперативно оценивать реальную современную эпидемиологическую опасность всего спектра фоновых видов грызунов, в первую очередь промысловых (сурки, суслики) и синантропных, повышать эффективность эпидемиологического надзора за контингентами высокого риска заражения. Ниже представлены эпизоотологические особенности состояния паразитарных систем 11 природных очагов чумы Российской Федерации в 2014 г. и прогноз на 2015 г.

Горно-Алтайский высокогорный очаг. В 2014 г. локальные эпизоотии зарегистрированы в КошАгачском районе Республики Алтай на площади 424,2 кв.км. Зараженные чумой животные выявлены на территории Уландрыкского и Тархатинского мезоочагов. Выделен 31 штамм возбудителя чумы, в том числе 29 алтайского подвида Y.pestis ssp. altaica (2 - от монгольской пищухи, 18 - от блох, собранных с этих зверьков, 8 - от блох из входов их нор, 1 - от блох с даурской пищухи) и 2 основного подвида $Y$. pestis ssp. pestis (1 - от больного человека, 1 - от серого сурка). Получены 18 положительных серологических результатов (от плоскочерепной полевки - 6, от монгольской пищухи - 10, от длиннохвостого суслика - 2). В 9 пробах погадок хищных птиц обнаружен капсульный антиген чумного микроба. Выявлены два новых эпизоотических участка - Междуречье Чаган-Бургазы-Тархата и Низ Чаган-Узуна. В костных останках сурка, собранных в долине р. Бар-Бургазы, методом ПЦР обнаружена ДНК чумного микроба основного подвида.

В сентябре 2014 г. впервые за время наблюдений (с 1961 г.) в Кош-Агачском районе Республики Алтай зарегистрировано заболевание человека чумой (бубонная форма). Заражение произошло при разделке тушки алтайского (серого) сурка, добытого в верховье р. Сербисту. Из 7 исследованных серых сурков из этого урочища от одного получена культура основного подвида $Y$. pestis ssp. pestis, второй послужил источником заражения человека (также возбудителем основного подвида). Последнее свидетельствует о том, что в высокогорных ландшафтах штаммы основного подвида $Y$. pestis ssp. pestis циркулируют преимущественно на участках, заселенных серым сурком. В 2014 г. численность монгольской пищухи в среднем по очагу составила весной 6,7 жилых нор на 1 га, осенью - 8,7 (среднемноголетние значения 4,9 и 6,8 соответственно). Численность даурской пищухи весной была равна 0,8 жилых нор на 1 га, осенью - 1,2 (многолетние показатели 0,7 и 1,5 coответственно). Плотность нор алтайского сурка на Уландрыкском участке очаговости составила весной 0,3 жилых бутанов на 1 га, летом - 0,6, осенью - 0,8; на Тархатинском участке очаговости - 0,3 жилых бутанов на 1 га. Наибольшая численность (0,9 жилых бутанов на 1 га) зарегистрирована в верховьях р. Бугузун. Численность длиннохвостого суслика осенью в среднем равнялась 4,9 особи на 1 га, что выше прошлогоднего $(3,5)$, но ниже среднемного- летних (5,5 особи на 1 га) значений. Показатель численности плоскочерепной полевки весной достигал 9,0 \% попадания в орудия лова, осенью - 30,2\%. На стоянках животноводов численность плоскочерепной полевки составляла весной 2,6 \%, осенью 3,8 \%; домовой мыши - 1,0 \%. В населенных пунктах в отловах доминировала домовая мышь (до 4,8 \%).

Численность блох монгольской пищухи по сравнению с предыдущим годом значительно возросла. Весной средний по очагу индекс обилия составил 12,7, осенью - 10,7 (2013 г. - 8,5 и 6,2 соответственно). Запас блох монгольской пищухи в весенний период равен 360 экз. на 1 га, в осенний - 544 (2013 г. 235 и 406). Возросли индексы обилия блох на второстепенных носителях. Средний за год показатель на даурской пищухе составил 10,8 (2013 г. - 6,4), на длиннохвостом суслике - $1,8(0,9)$ на плоскочерепной полевке - $1,3(1,0)$.

В 2015 г. прогнозируется развитие локальных эпизоотий чумы на территории Кош-Агачского района Республики Алтай в границах Уландрыкского, Тархатинского и Курайского участков очаговости. Сохраняется вероятность выявления новых участков циркуляции возбудителя чумы основного подвида в поселениях алтайского сурка и длиннохвостого суслика. Показатели численности монгольской пищухи и обилия ее блох существенно не изменятся. В связи с подтверждением широкого распространения высоковирулентных штаммов основного подвида чумного микроба Y.pestis ssp. pestis по территории очага его потенциальная эпидемическая опасность резко возросла. Необходимо провести дифференциацию очаговой территории по степени потенциальной эпидемической опасности, разработать регламент эпизоотологического обследования, повысить противоэпидемическую готовность медицинских учреждений на участках повышенного риска заражения.

Прикаспийский песчаный очаг. В 2014 г. отмечен взрывной характер обострения эпизоотологической обстановки в центральной приморской части очага. Эпизоотии выявлены на территории Лиманского района Астраханской области, Лаганского и Черноземельского районов Республики Калмыкия, Тарумовского района Республики Дагестан (рис. 1). Общая площадь эпизоотии составила 2300 кв.км. Выделено 53 штамма Y. pestis: 17 культур было изолировано от грызунов (9 - от полуденной и 4 - от гребенщиковой песчанок, 2 - от домовой мыши, по одному - от общественной полевки и малого тушканчика), 36 культур получено от их блох $(17$ - от $N$. laeviceps, 5 - от $X$. conformis, 8 от $N$. mokrzeckyi, 3 - от $N$. consimilis и 3 штамма от блох без определения вида). Методами ПЦР и ИФА подтверждена циркуляция Y. pestis в центральной и южной частях очага.

Активизация очага в 2014 г. произошла на фоне высокой численности носителей и переносчиков чумы. Весной общая численность перезимовавших популяций грызунов составила 31,1 особи на 1 га. 


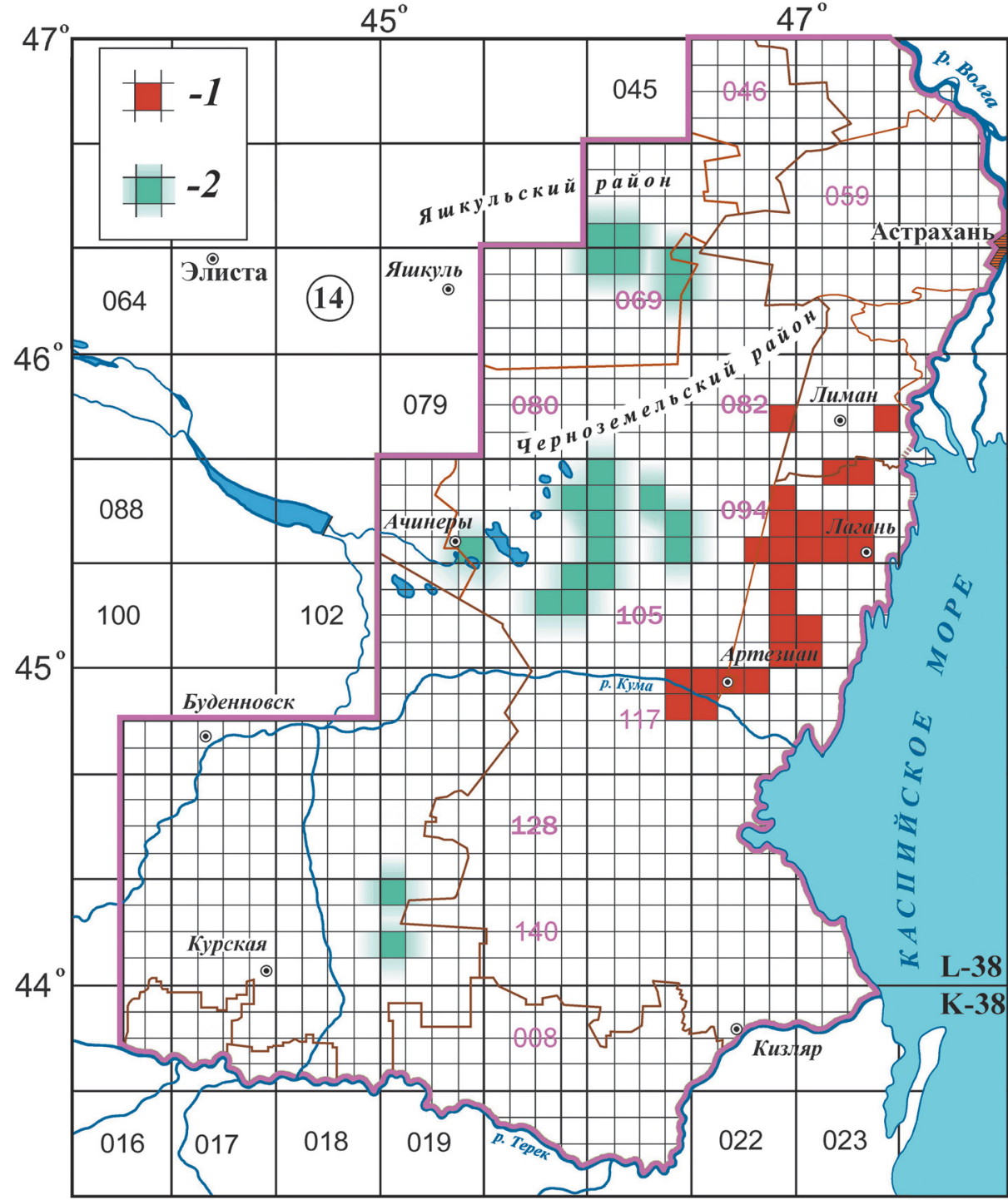

Рис. 1. Особенности пространственного распределения эпизоотических участков на территории Прикаспийского песчаного природного очага:

1 - участки выделения культур чумного микроба в 2013-2014 гг;; 2 - участки обнаружения маркеров возбудителя чумы молекулярногенетическими методами

Плотность основных носителей - малых песчанок равнялась 9,4 особи на 1 га, что в 2,4 раза больше средней многолетней $(3,9)$. К осени, после жаркого лета, плотность малых песчанок снизилась до 3,7 особи на 1 га, что меньше многолетней величины $(5,2)$. В Кумо-Манычском междуречье плотность песчанок превышала многолетние показатели для этого участка очага и составляла весной 3,9 , осенью - 7,4 особи на 1 га. В Терско-Кумском междуречье плотность песчанок составляла весной 0,9 , осенью - 0,8 особи на 1 га. Фоновым и самым многочисленным видом повсеместно является общественная полевка, средняя численность которой весной достигала 17,7 особи на 1 га, осенью - 9,7. Сохраняется тенденция снижения численности малого суслика $-1,2$ особи на 1 га, что втрое ниже нормы $(3,0)$. В Волго-Кумском междуречье численность мышевидных грызунов весной равнялась 7,0, летом - 4,2, осенью - 4,3 \% попадания в орудия лова. В Кумо-Манычском междуречье численность мышевидных грызунов достигала весной 13,6 , осенью - 4,6 \%. Показатели численности мышевидных грызунов в Терско-Кумском междуречье не превышали 1,5%. В населенных пунктах средние показатели численности домовой мыши были не выше 3,3 \% весной и 4,0 осенью, что в 1,5 раза ниже многолетних значений. Заселенность объектов варьировала от 20 до $30 \%$.

Индексы обилия блох в шерсти грызунов на территории Волго-Кумского междуречья значительно превысили многолетние показатели и составляли: на полуденной песчанке - 1,3; на гребенщиковой песчанке $-5,0$; на сером хомячке $-4,4$; на общественной полевке $-2,3$; на домовой мыши - 0,4. Запас блох песчанок на 1 га достигал весной 350, осенью - 120 экземпляров. В Терско-Кумском и Кумо-Манычском междуречьях отмечены низкие показатели обилия блох на 1 га. В Кумо-Манычском междуречье при обследовании 9 поселков на площади 9,8 тыс. кв.м в домах обнаружены блохи 3 видов: Pulex irritans, Ctenocephalides canis и N. mokrzeckyi.

В весенний период 2015 г. прогнозируется спад эпизоотической активности очага на фоне низкой численности носителей и переносчиков чумы. Развитие локальных эпизоотий ожидается на территории Лиманского района Астраханской области, Лаганского и Черноземельского районов Республики 
Калмыкия, Тарумовского района Республики Дагестан и Курского района Ставропольского края. В связи с высокой вероятностью расширения границ эпизоотии в западном направлении (Черноземельский район Республики Калмыкия, Курский район Ставропольского края) необходимо значительно усилить эпидемиологический надзор за этими территориями в весенний период 2015 г.

Тувинский горный очаг. В 2014 г. эпизоотии зарегистрированы на территории Монгун-Тайгинского кожууна и Овюрского кожууна Республики Тыва на площади 1166 кв.км (2013 г. - 1109 кв.км). Выделено 44 штамма Y. pestis (2013 г. - 38), в том числе от длиннохвостого суслика - 4; блох видов: C. tesquorum - 27, $N$. mana $-3, F$. hetera - 2, F. elatoides - 1, O. alaskensis - 1; от гамазовых клещей с длиннохвостого суслика -1 , от вшей с длиннохвостого суслика -1 , от личинок клеща $D$. nuttalli - 3, от нимфы $D$. nuttalli из входа нор длиннохвостого суслика -1 . Получено 115 положительных результатов иммунологических исследований, в том числе: от длиннохвостого суслика -109 , от трупа длиннохвостого суслика -1 , от даурской пищухи - 3, от плоскочерепной полевки 1 , от каменки плясуньи - 1 . Эпизоотические проявления зарегистрированы на Каргинском, Борошайском, Толайлыгском, Барлыкском, Кара-Бельдырском, Саглинском и Чозовском участках.

Численность длиннохвостого суслика в 2014 г. в очаге возросла до 4,7 особи на 1 га $(2013$ г. - 4,1). Средняя плотность нор тарбагана по очагу составила 1,3 жилых бутанов на 1 га (2013 г. - 1,5). На большей части очага сохраняется глубокая депрессия численности монгольской пищухи. В Монгун-Тайгинском мезоочаге она снизилась до 1,5 жилых колоний на 1 га (2013 г. - 3,3). Показатель численности даурской пищухи остался на уровне предыдущего года - 0,9 жилых колоний на 1 га; плоскочерепной полевки составил $1,5 \%$ попадания в орудия лова. На чабанских стоянках в Монгун-Тайгинском мезоочаге в летний период численность грызунов (в основном плоскочерепной полевки) снизилась до 6,2 \% (2013 г. 16,6 \%). Средний показатель численности тарбагана составил 1,5 жилых бутанов на 1 га. Особенно напряженная эпидемиологическая обстановка сохраняется на Борошайском участке, где в 2012 г. выделены культуры чумы от трупа тарбагана и его эктопаразитов (ур. Боро-Шай).

В Монгун-Тайгинском мезоочаге обилие блох на длиннохвостом суслике составило 3,4 (2013 г. $3,7)$, во входах нор - 0,16 $(0,24)$; в гнездах $-75,0$ $(38,7)$. В целом по очагу индекс обилия блох на длиннохвостом суслике снизился до 3,3 (2013 г. - 3,6). Зарегистрирован рост плотности населения вшей в шерсти длиннохвостого суслика, индекс обилия составил 3,6 (2013 г. - 0,7), а также гамазовых клещей, их индекс обилия возрос до 0,1 (2013 г. - 0,05). Отмечена тенденция роста численности иксодовых клещей $D$. nuttalli - индекс обилия личинок и нимф на длиннохвостом суслике равен 13,1 (2013 г. - 12,2).
На второстепенных носителях индексы обилия эктопаразитов остаются на низком уровне. В населенных пунктах блох не обнаружено.

В 2015 г. прогнозируется сохранение высокой эпизоотической активности мезоочагов чумы на территории Монгун-Тайгинского и Овюрского кожуунов Республики Тыва. Показатели численности длиннохвостого суслика и его блох существенно не изменятся. В связи с высокой вероятностью развития эпизоотий чумы в смежных поселениях монгольских сурков и длиннохвостого суслика на территории Овюрского кожууна (Борошайский участок) необходимо значительно усилить здесь эпидемиологический надзор в 2015 г.

Центрально-Кавказский высокогорный природный очаг. В 2014 г. возбудитель чумы не выделен. Методом ПЦР подтверждена циркуляция Y. pestis на территориях Верхне-Кубанского, КубаноМалкинского, Малко-Баксанского ландшафтноэпизоотологических районов (ЛЭР) очага (получено 33 положительных результата).

Средняя численность горного суслика в целом по очагу составила 22,5 особи на 1 га, что практически соответствует уровню прошлого года $(22,0)$. В различных ЛЭР показатели численности составляли: в Верхне-Кубанском - 25,5; Кубано-Малкинском - 19,5; Малко-Баксанском - 25,0; БаксаноЧерекском - 20,0 особей на 1 га. Отмечена тенденция восстановления поселений горного суслика в окрестностях кошар частного пользования. На ксерофитных участках горной степи численность зверьков не превышала 12-15 особей на 1 га. Блоха C. tesquorum, являющаяся основным переносчиком в очаге, доминировала во всех высотных поясах и составляла в горной степи $79,6 \%$, в субальпике 89,9 и зоне альпийских лугов $-83,2 \%$. Численность этого вида в 2014 г. на различных участках очага оказалась ниже аналогичных показателей 2013 г. На территории Верхне-Кубанского ЛЭР индексы обилия блох составляли в горной степи 4,2 - на сусликах, 5,0 - в гнездах зверьков и 0,5 - во входах нор; в зоне субальпийских лугов $-9,4$ и 1,4 и на альпийских лугах $-2,4$ и 1,7 на зверьках и их гнездах соответственно. Состояние популяций основного переносчика перед залеганием в спячку не предполагает роста численности в 2015 г. Средний показатель численности мышевидных грызунов составил 7,6\% попадания в орудия лова (2013 г. - 7,0\%). Численность обыкновенной полевки равнялась в среднем $8,0 \%$. В луговых стациях, где обитает горный суслик, численность лесной и домовой мышей возросла до 2,0 \% (2013 г. - 1\%). В населенных пунктах численность мышевидных грызунов колебалась в пределах 5-15\% попадания в орудия лова. Отмечено обитание серой крысы в различных типах объектов на территории н.п. Тырныауз и Былым.

В 2015 г. показатели численности горного суслика сохранятся на уровне среднемноголетних значений. Индексы обилия блох существенно не изменят- 
ся. Сохраняется вероятность обнаружения единично зараженных чумой животных.

Терско-Сунженский низкогорный природный очаz. С 2001 г. зараженных животных в очаге не выявлено. На территории Терского и Сунженского хребтов малый суслик встречается спорадически. Общая площадь поселений носителя не превышает 3 тыс. га. Средняя плотность зверьков составляет 0,1 особи на 1 га. Средний процент попадания мышевидных грызунов в природных биотопах достигал весной и осенью 5,9 \% (2013 г. - 12,6 \%, среднемноголетнее значение $-3,7$ \%). Индексы обилия блох на мелких мышевидных грызунах не превышали 1,0, в том числе на лесных мышах - 0,5, на домовых мышах - 0,4. В 2015 г. эпизоотических проявлений на территории очага не ожидается. Сохранится депрессия численности малого суслика. Численность мышевидных грызунов весной составит 3-4 \% попадания в орудия лова.

Дагестанский равнинно-предгорный природный очаг. С 2004 г. зараженных животных на территории очага не зарегистрировано. В равнинной зоне средние показатели численности малого суслика возросли до 4,3 особи на 1 га (2013 г. - 3,7; среднемноголетний показатель - 0,8). На севере Аграханского полуострова выявлено новое поселение малого суслика площадью свыше 1 тыс. га и плотностью зверьков более 15 особей на 1 га. В предгорной части средняя плотность малого суслика не превышала 2,7 особи на 1 га (2013 г-2,8; среднемноголетнее значение - 6,8). Показатель средней численности гребенщиковой песчанки весной достигал 5,0 особей на 1 га (весна 2013 г. - 4,6; среднемноголетнее значение $-6,4)$. Фоновая численность песчанок от весны к осени уменьшилась до 2,9 особи на 1 га (2013 г. 5,0; среднемноголетнее значение - 7,6). Показатель численности мышевидных грызунов весной в предгорной зоне достигал 2,7 \% попадания в орудия лова (2013 г. - 1,2; среднемноголетнее значение - 3,4); в равнинной зоне не превышал 2,0 \% (2013 г. - 0,9; среднемноголетний показатель - 2,1). Осенью численность мышевидных грызунов в предгорной зоне снизилась до 6,9 \% (2013 г. - 11,3; среднемноголетнее значение - $10,3 \%$ ); в равнинной зоне возросла до $13,9 \%$ (2013 г. - 4,5 и 8,3\%). Отмечено сохранение низкой численности блох грызунов на территории очага. В равнинной части запас эктопаразитов малого суслика весной не превышал 10 экз. на 1 га (2013 г. 61 ; среднемноголетний показатель - 18); летом вырос до 52 экз. (среднемноголетняя норма - 28). В предгорной зоне весенний запас снизился до 91 экз. на 1 га (2013 г. - 120; среднемноголетнее значение 156); летом он достиг 116 экз. на 1 га (2013 г. - 165 и 55). Запас блох гребенщиковой песчанки весной не превышал 7,0 экз. на 1 га (2013 г. - 5,0; среднемноголетнее значение - 23,5); осенью составил 7,8 экз. (2013 г. - 4,0; среднемноголетнее значение - 17,0).

В 2015 г. прогнозируется сохранение тенденции роста численности и площади поселений малого суслика в равнинной части очага. Возможны находки единичных зараженных животных на локальных участках в совместных поселениях малого суслика и гребенщиковой песчанки.

Прикаспийский Северо-Западный степной очаг. В 2014 г. эпизоотий чумы на территории очага не зарегистрировано. Популяции малого суслика и его специфических эктопаразитов продолжают оставаться в состоянии глубокой депрессии. В 2014 г. выход сусликов на поверхность почвы отмечен в январе, а массовое пробуждение произошло в первой декаде февраля, что значительно раньше обычных сроков. Средний показатель численности суслика по очагу составил около 4 особей на 1 га (2013 г. - 5,7; среднемноголетнее значение - 9,6). На севере, юге и восточных склонах Ергенинской возвышенности показатели численности зверьков достигали 3 особей на 1 га, на западных склонах поселений сусликов не выявлено. На Черных землях показатели численности сусликов снизились до 2,8 особи на 1 га. В северной части очага, в том числе на территориях Сарпинской низменности и лощины Даван, в окрестностях стоянок животноводов численность сусликов достигает 11 особей на 1 га.

В природных биотопах фоновые показатели численности мышевидных грызунов составляли весной 3-8, осенью - 5-10 \% попадания в орудия лова. В северной части очага на отдельных участках численность мышевидных грызунов достигала 34,3-48,2 \%. Во многих биотопах, наряду с домовой мышью, в качестве субдоминанта отмечена общественная полевка. На Черных землях индекс доминирования общественной полевки достигал $40 \%$. Численность домовой мыши в населенных пунктах не превышала весной 3,3 , осенью - 4,4 \% попадания в орудия лова. Заселенность жилых домов мышевидными грызунами равнялась 14-47\%. Численность блох малого суслика на Ергенях достигала 380, в Низменно-солонцеватых степях - 197, на Черных землях - 267 экз. на 1 га, что выше прошлогоднего уровня, но существенно ниже среднемноголетнего. Индексы обилия блох на мышевидных грызунах повсеместно низкие. В населенных пунктах блох не зарегистрировано.

В 2015 г. в очаге сохранится низкий уровень численности носителей и переносчиков чумы. Развитие эпизоотий чумы в очаге маловероятно.

Волго-Уральский степной очаг. Последние находки зараженных животных в западной (российской) части очага отмечены в 1975 г., на территории Казахстана - в 2001 г. В границах Астраханской и Волгоградской областей сохраняется глубокая депрессия численности малого суслика. Средний показатель плотности суслика составляет здесь 2,4 особи на 1 га, что значительно ниже среднемноголетнего значения $-8,8$.

Средняя численность мышевидных грызунов в природных биотопах весной возросла до $10,7 \%$ (2013 г. -7,9), осенью - до 12,7 (2013 г. - 9,6) попада- 
ния в орудия лова. В населенных пунктах численность мышевидных грызунов составляла 5,3 \% (2013 г. -3,0). В 2014 г. заселенность объектов грызунами в среднем достигала 22,4 \% (2013 г. - 15,6). Общий запас блох малого суслика сохранился на низком уровне - 66 экз. на 1 га (2013 г. - 61; средняя многолетняя величина 368). Индексы обилия блох на мышевидных грызунах повсеместно низкие. В населенных пунктах блох не обнаружено.

В 2015 г. в очаге сохранится низкий уровень численности малого суслика и его блох. Численность мышевидных грызунов не превысит уровня средних многолетних значений. Развитие эпизоотий чумы в очаге маловероятно.

Забайкальский степной очаз. С 1971 г. проявлений чумы не зарегистрировано. В очаге сохраняется низкий уровень численности даурского суслика. Средний показатель плотности зверьков составлял весной 0,3 особи на 1 га, летом - 0,5. На локальных участках вблизи населенных пунктов и стоянок животноводов численность суслика несколько выше (2-3 особи на 1 га). Монгольский сурок или тарбаган на территории очага встречается редко: обитает на отдельных труднодоступных участках в гористой местности. Однако местами, где проводят природоохранные мероприятия, отмечается расширение площади поселений монгольского сурка. На территории Олдондинского заказника в среднем его плотность составляет 0,4 жилых бутанов на 1 га, на локальных участках достигает 1,7-2,0 жилых бутанов на 1 га. Показатели численности даурского хомячка в оптимальных биотопах варьировали в пределах 0-8 \% попадания в орудия лова (в среднем 1,8). Численность хомячка Кэмпбелла не превышала 0,5 \% (в среднем $0,08)$. Средний показатель плотности даурской пищухи не превышал весной - 0,4 жилых нор на 1 га, осенью - 0,9. Численность полевок (узкочерепной, монгольской и Брандта) оставалась на очень низком уровне. В населенных пунктах средняя численность домовой мыши равнялась 1,0 \% попадания в орудия лова. Средние индексы обилия блох повсеместно низкие. На отдельных участках индекс обилия блох составлял на даурском суслике 4,1, на дурской пищухе $-1,4$, на стадной полевке $-1,8$.

В 2015 г. в очаге сохранится низкий уровень численности даурского суслика и его блох. Проявлений чумы в очаге не ожидается.

Волго-Уральский песчаный очаг. Последние эпизоотические проявления на территории Российской Федерации отмечены в 2005 г. В 2014 г. неблагоприятные погодные факторы весенне-летнего периода оказали негативное влияние на состояние численности фоновых видов грызунов и их специфических эктопаразитов. Весной показатель численности песчанок почти вдвое превышал среднемноголетнее значение (4,9 особи на 1 га) и составлял для полуденной песчанки 2,8, для гребенщиковой - 5,6 особи на 1 га. Сезонного увеличения численности песчанок в летне-осенний период не произошло. Осенний по- казатель численности песчанок был в 1,3 раза ниже среднемноголетнего значения (9,9 особи на 1 га) и составлял для полуденной песчанки - 2,7, гребенщиковой песчанки - 4,7 особи на 1 га. Численность мышевидных грызунов весной составляла 5,2, осенью сократилась до 1,6 \% попадания в орудия лова. В населенных пунктах численность мышевидных грызунов весной не превышала 2,2, осенью - 1,8 \% при заселенности объектов $16 \%$. В связи с высокой исходной весенней численностью песчанок общий запас их блох несколько превысил уровень 2013 г. и составил весной 114 экз., осенью возрос до 480 экз. на 1 га. Все эти показатели в 2-3 раза ниже среднемноголетних значений. В населенных пунктах насекомых не выявлено.

В 2015 г. в очаге сохранится низкий уровень численности носителей и переносчиков возбудителя чумы. Проявлений чумы в очаге не ожидается.

Восточно-Кавказский высокогорный природный очаг. В 2014 г. в очаге возбудитель чумы не обнаружен. Средняя численность обыкновенной полевки в горной зоне весной составила 3,7 особи на 1 га (2013 г. - 3,5; среднемноголетнее значение - 3,2). К осени средняя плотность полевок снизилась до 3,2 особи на 1 га (2013 г. - 5,0; среднемноголетнее значение - 11,9). В предгорной зоне численность полевок осенью составила 3,9 особи на 1 га (2013 г. - 3,8; среднемноголетнее значение $-8,7)$. В горной зоне численность мышевидных грызунов в природных биотопах составила весной 1,2 \% попадания в орудия лова (2013 г. - 1,9; среднемноголетнее значение - 2,9), осенью - 1,8 (2013 г. - 1,5; среднемноголетнее - 8,3). В предгорной зоне осенняя численность мышевидных грызунов достигала 6,9 \% (2013 г. - 5,3; среднемноголетнее значение - 10,3). В населенных пунктах осенняя численность мышевидных грызунов в предгорной зоне составляла 3,1 ; в горной - 0 \%.

В горной и предгорной зонах отмечена очень низкая численность блох обыкновенной полевки. В горной зоне запас блох весной составлял 2,6 экз. на 1 га (2013 г. - 4,3; среднемноголетнее значение $-53,2)$, к осени - увеличился до 8,3 экз. на 1 га (2013 г. - 6,0, среднемноголетнее значение - 231). В предгорной зоне этот показатель составлял 6,2 экз. на 1 га (среднемноголетнее значение - 161). Индекс обилия блох на лесной мыши составил 0,15 ; домовой мыши - 0,02; общественной полевке - 0,2. На сером хомячке и полевой мыши блох не обнаружено.

В 2015 г. в очаге прогнозируется низкий уровень численности носителей и переносчиков возбудителя чумы. Сохраняется вероятность обнаружения единичных зараженных животных на участках стойкого проявления чумы.

Представленные выше материалы служат основой для обоснования прогноза на сохранение напряженной эпидемиологической обстановки в природных очагах чумы Северо-Западного Прикаспия и Сибири. В 2015 г. развитие эпизоотий ожидается на территории Прикаспийского песчаного, Горно- 


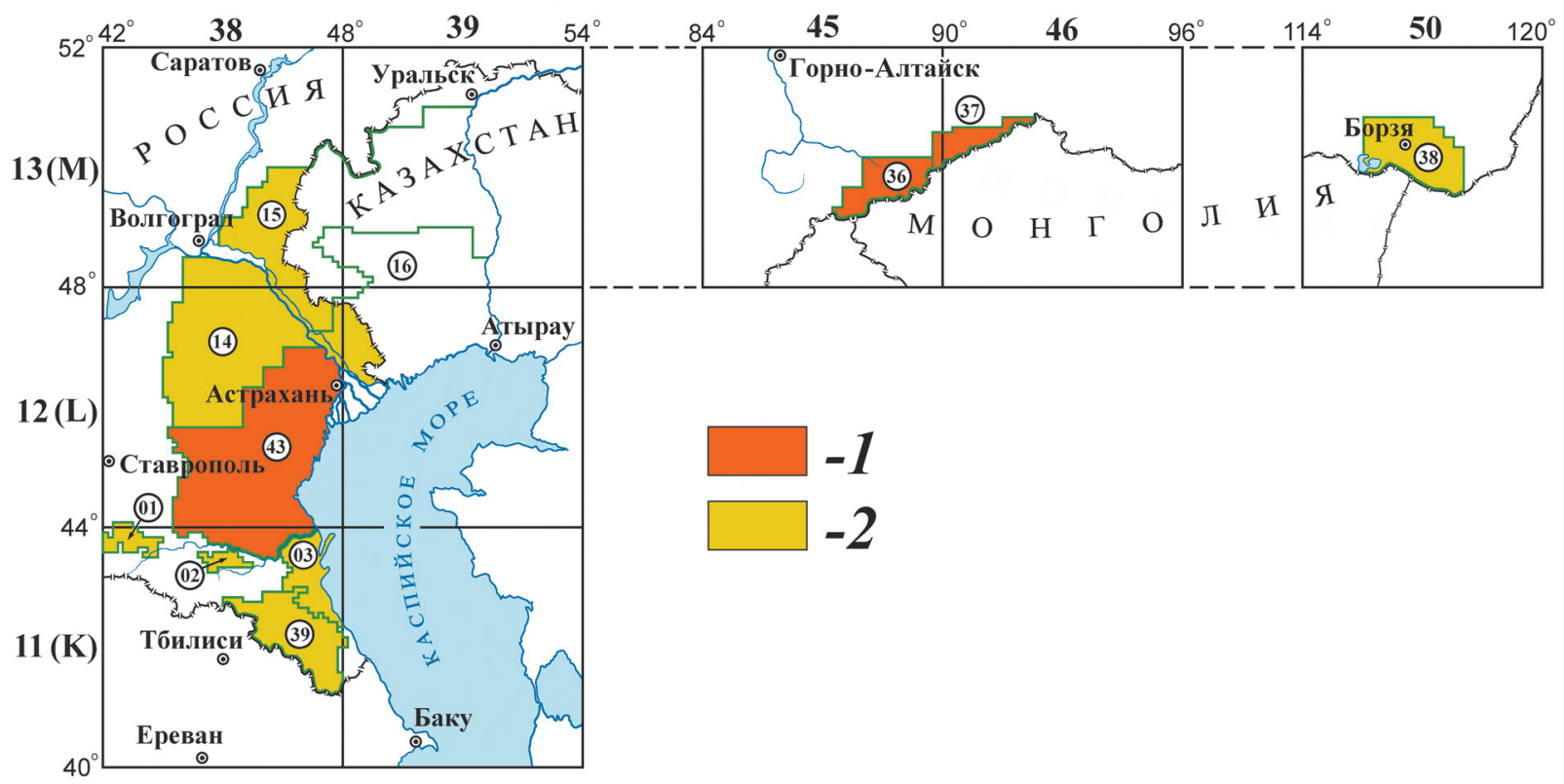

Рис. 2. Прогноз эпизоотической активности природных очагов чумы Российской Федерации на 2015 г.:

1 - сохранение эпизоотической активности; 2 - сохранение межэпизоотического периода

Алтайского высокогорного, Тувинского горного природных очагов чумы (рис. 2). В остальных очагах прогнозируется отсутствие эпизоотий, хотя находки единично зараженных животных не исключены.

Авторы подтверждают отсутствие конфликта финансовых/нефинасовых интересов, связанных с написанием статьи.

\section{СПИСОК ЛИТЕРАТУРЫ}

1. Кутырев В.В., Попова А.Ю., Ежлова Е.Б., Демина Ю.В., Пакскина Н.Д., Щучинов Л.В., Михайлов Е.П., Мищенко А.И., Рождественский Е.Н., Базарова Г.Х, Денисов А.В., Шарова И.Н., Попов Н.В., Кузнецов А.А. Заболевания человека чумой в Горно-Алтайском высокогорном природном очаге в 2014 г. Сообщение 1. Эпидемиологические и эпизоотологические особенности проявлений чумы в Горно-Алтайском высокогорном (Сайлюгемском) природном очаге чумы. Пробл. особо опасных инф. 2014; 4:9-16.

2. Онищенко Г.Г., Кутырев В.В., редакторы. Природные очаги чумы Кавказа, Прикаспия, Средней Азии и Сибири. М.: Медицина; 2004. 192 с.

3. Попов Н.В., Безсмертный В.Е., Топорков В.П., Матросов А.Н., Князева Т.В., Кузнецов А.А., Попов В.П., Вержуцкий Д.Б., Корзун В.М., Чипанин Е.В., Дуб̆янский В.М., Малецкая О.В. Григорьев М.П., Балахонов С.В., Куличенко А.Н., Кутырев В.В. Эпизоотическая активность природных очагов чумы Российской Федерации в 2013 г. и прогноз на 2014 г. Пробл. особо опасныих инф. 2014; 2:13-8.

\section{References}

1. Kutyrev V.V., Popova A.Yu., Ezhlova E.B., Demina Yu.V., Pakskina N.D., Shchuchinov L.V., Mikhailov E.P., Mishchenko A.I., Rozhdestvensky E.N., Bazarova G.Kh., Denisov A.V., Sharova I.N., Popov N.V., Kuznetsov A.A. [Infection of an individual with plague in the Gorno-Altaisk highmountain natural focus in 2014. Communication 1. Epidemiological an epizootiological peculiarities of plague manifestations in the Gorno-Altaisk high-mountain (Sailyugemsky) natural plague focus]. Probl. Osobo Opasn. Infek. 2014; 4:9-16
2. Onishchenko G.G., Kutyrev V.V., editors. [Natural Plague Foci in Caucasus, Caspian Sea Region, Central Asia, and Siberia]. M.: Meditsina; 2004. $192 \mathrm{p}$.

3. Popov N.V., Bezsmertny V.E., Toporkov V.P. Matrosov A.N. Knyazeva T.V., Kuznetsov A.A., Popov V.P., Verzhutsky D.B., Korzun
V.M. Chipanin E.V., Dubyansky V.M., Maletskaya O.V., Grigoryev M.P., Balakhonov S.V., Kulichenko A.N., Kutyrev V.V. [Epizootic activity of natural plague foci in the Russian Federation in 2013 and prognosis for the year of 2014]. Probl. Osobo Opasn. Infek. 2014; 2:13-8.

Authors:

Popov N.V., Matrosov A.N., Knyazeva T.V., Kuznetsov A.A., Kutyrev V.V. Russian Research Anti-Plague Institute "Microbe". 46, Universitetskaya St., Saratov, 410005, Russian Federation. E-mail: rusrapi@microbe.ru

Bezsmertny V.E. Fedorov Yu.M. Popov V.P. Plague Control Center. 4, Musorgskogo St., Moscow, 127490, Russian Federation. E-mail: protivochym@nln.ru

Verzhutsky D.B., Korzun V.M., Chipanin E.V., Balakhonov S.V. Irkutsk Research Anti-Plague Institute of Siberia and Far East. 78, Trilissera St., Irkutsk, 664047, Russian Federation. E-mail: adm@chumin.irkutsk.ru

Dubyansky V.M., Maletskaya O.V., Grigor'ev M.P., Kulichenko A.N. Stavropol Research Anti-Plague Institute. 13-15, Sovetskaya St., Stavropol, 355035, Russian Federation. E-mail: snipchi@mail.stv.ru

\section{Об авторах:}

Попов Н.В., Матросов А.Н., Князева Т.В., Кузнещов А.А., Кутырев $B . B$. Российский научно-исследовательский противочумный институт «Микроб». Российская Федерация, 410005, Саратов, ул. Университетская, 46. E-mail: rusrapi@microbe.ru

Безсмертный В.Е., Федоров Ю.М., Попов В.П. Противочумный центр. Российская Федерация, 127490, Москва, ул. Мусоргского, 4 E-mail: protivochym@nln.ru

Вержуикий Д.Б., Корзун В.М., Чипанин Е.В., Балахонов С.В. Иркутский научно-исследовательский противочумный институт Сибири и Дальнего Востока. Российская Федерация, 664047, Иркутск, ул. Трилиссера, 78. E-mail: adm@chumin.irkutsk.ru

Дубянский В.М., Малечкая О.В., Григорьев М.П., Куличенко А.Н. Ставропольский научно-исследовательский противочумный институт. Российская Федерация, 355035, Ставрополь, ул. Советская, 13-15. E-mail: snipchi@mail.stv.ru

Поступила 29.01.15 